$1-1-2016$

\title{
The Institutionalization of Supreme Court Confirmation Hearings
}

Paul M. Collins Jr.

University of Massachusetts - Amherst

Lori A. Ringhand

University of Georgia School of Law, ringhand@uga.edu

b bepress $S S R N$

\section{Repository Citation}

Paul M. Collins Jr. and Lori A. Ringhand, The Institutionalization of Supreme Court Confirmation Hearings , 41 L. \& Soc. Inquiry 126 (2016),

Available at: https://digitalcommons.law.uga.edu/fac_artchop/1070

This Article is brought to you for free and open access by the Faculty Scholarship at Digital Commons @ University of Georgia School of Law. It has been accepted for inclusion in Scholarly Works by an authorized administrator of Digital Commons @ University of Georgia School of Law. Please share how you have benefited from this access For more information, please contact tstriepe@uga.edu. 
These changes can be usefully thought of as involving two major types of developments: the advent of public hearings in 1939 in which the nominee is expected to answer unrestricted questions from the senators; and the changing nature and content of the questions posed to nominees. These latter developments include a rise in the number of hearing comments, particularly in the 1980s; increased attention to nominees' views of judicial decisions beginning in the 1960s; an expansion of the scope of issues addressed starting in the 1970s; and the equalization of questioning between majority and minority party senators that first took place in the 1980s. Placing these changes in their institutional context, as we do below, makes it easier for us to explore why they have occurred.

To demonstrate this, we engage work concerned with how political entities become institutionalized (Squire 1992; Swift 1996; Ragsdale and Theis 1997; McGuire 2004; Vining, Zorn, and Smelcer 2006; Crowe 2012). By institutionalization, we are referring to the means by which institutions adopt regularized procedures that enable them to fulfill their given tasks (Huntington 1965; Hibbing 1988; McGuire 2004). Over time, institutions embrace certain characteristics that facilitate the achievement of a distinct identity and way of doing things (Ragsdale and Theis 1997, 1282). This results in the institution achieving a level of selfmaintenance as the organization becomes prized "for its own sake" and develops an identity that is uniquely its own (Selznick 1957, 17).

As it applies to the Judiciary Committee and the Supreme Court confirmation process, we view the primary task of the Committee as being to aid the Senate in performing its advice and consent role; that is, to assist senators in making informed decisions as to whether to support or oppose a nominee's appointment to the Court (Epstein and Segal 2005; Williams and Baum 2006; Ringhand and Collins 2011). Institutionalization, then, refers to the procedures the Committee adopts to fulfill this role and stake out its unique identity in the Supreme Court confirmation process. While this has occurred in a variety of ways, our primary focus in this article is on the most visible, and arguably the most significant, role of the Committee: the development of the Supreme Court confirmation hearings in the 1939-2010 era. ${ }^{1}$

Through these question and answer sessions, senators are able to examine nominees on a host of topics, including their backgrounds, judicial philosophies, understanding of existing precedent, and views on the most pressing issues facing society (Ringhand and Collins 2011; Batta et al. 2012). The nominees' responses, made in public and under oath, provide substantial information to senators and the US public, potentially shaping these actors' views of the nominees' fitness for the high bench. As a result, the hearings can affect the fate of the nomination before both the Judiciary Committee and the full Senate (Watson and Stookey 1988; Wedeking and Farganis 2010; Collins and Ringhand 2013).

1. Other notable developments relating to the Judiciary Committee's place in the broader confirmation process include the changing role of interest groups (Maltese 1995) and the evolution of judicial selection to the lower courts (Goldman 1997). 
We illustrate how various actors shape institutional developments for both legitimating and instrumental purposes (Hall and Taylor 1996; Pierson 2000). ${ }^{2}$ By legitimating, we mean that institutional arrangements are adopted to promote social acceptance of the activities of the institution. In this sense, norms develop that are viewed as appropriate in light of the institution's role in the political process. As the institution gains legitimacy, its value as a unique and venerable part of the governing system grows (Meyer and Rowan 1977). Institutions seek to gain legitimacy both to foster the public's acceptance of the institution and to enhance the power of the institution in the governing system (Fenno 1962). By instrumental, we mean that institutional change is motivated by goal-seeking behavior. That is, institutions develop that promote the ability of actors in those institutions to achieve various ends (Pierson 2000).

We use an original dataset of confirmation hearing dialogue to demonstrate how membership on the Judiciary Committee allows senators to pursue both legitimating and instrumental goals. Grounding our discussion of these changes in these data allows us to explore them carefully in their full institutional context, thereby more clearly revealing the legitimating and instrumental goals they advanced, as well as the way they intersect with each other, and with external events.

Documenting this transformation is important for a number of reasons. First, it contributes to our understanding of change in political institutions by illustrating how the role of one of the most visible Senate standing committees has evolved over time. As we demonstrate, what began as a largely inconspicuous body has become one of the most public examples of checks and balances in the entire political system. Despite this, we lack a firm grasp on the developments that led to this evolution. ${ }^{3}$ Second, this research illuminates how changes in one institution can affect those in another, furthering our understanding of interbranch relations. We show that as the salience of the Supreme Court in US politics expanded in the 1950s, the dynamics of the Senate Judiciary Committee hearings changed to give enhanced public scrutiny to potential members of the Court. Third, this research further corroborates how institutional change affects the behavior of political actors (March and Olsen 1984; Hall and Taylor 1996). For example, we demonstrate how gavel-to-gavel television coverage of the hearings beginning in 1981 enhanced the ability of senators to use the hearings to convey information to their constituents.

2. An alternative framework for understanding institutional development is to view change in light of measures related to durability, autonomy, and differentiation (Huntington 1965). While we believe that such an approach can be very useful, it is better suited to understanding the development of large-scale institutions, such as the House of Representatives (Polsby 1968) or the Supreme Court (McGuire 2004), as opposed to smaller-scale bodies operating within a larger institutional setting (Fenno 1962). For example, salaries and expenditures, often used as a proxy for durability, are determined at the large-scale institution level (i.e., House or Supreme Court), not at the committee level. Similarly, an institution's ability to set its own agenda, which captures autonomy, does not apply to Supreme Court confirmation hearings since nominations must be referred to the Senate Judiciary Committee by the Senate. However, we recognize that differentiation - carving out a unique identity - is related to the legitimacy of an institution and incorporate this concept into our discussion of the development of the hearings.

3. Although we provide a descriptive account of the institutionalization of the confirmation hearings in this article by drawing on both qualitative and quantitative data, the Appendix reports the results of statistical models of hearing change. These models corroborate that the changes we identify in the article are significant when controlling for other influences on hearing development. 
We argue that senators took advantage of this for instrumental reasons, as it allowed them to position take, credit claim, and advertise in a high-profile forum, thus enhancing their reelection prospects (Mayhew 1974). Taken as a whole, this research informs our understanding of institutional change, the Senate's advice and consent role, institutional interactions, and the behavior of political actors.

\section{NOMINEE TESTIMONY}

The Constitution says very little about the confirmation process beyond charging the president with nominating judges to the Supreme Court and the Senate with confirming them. Further, it makes no mention of the congressional committee structure that is a major feature of the contemporary Senate. Prior to the creation of the Judiciary Committee in 1816, the Senate as a whole handled Supreme Court nominations in private without the benefit of confirmation hearings (Rutkus and Bearden 2009; Beth and Palmer 2011).

The first move toward the process we know today occurred in 1816, when the Senate established the Committee on the Judiciary as a standing committee, along with eleven other standing committees (Gamm and Shepsle 1989, 50). Despite the fact that overseeing the federal judiciary was part of its original charge, not all Supreme Court nominations were referred to the new Judiciary Committee. From 1816-1867, only two-thirds of Supreme Court nominations reached the Committee, all by motion. However, in 1868, the Senate began automatically referring Supreme Court nominations to the Committee. Since this date, all but six nominations have been referred to the Committee (Rutkus 2010). ${ }^{4}$ This revision had the effect of differentiating the role of the Committee from the chamber as a whole, thus marking an early contribution to the development of its unique identity in the confirmation process.

\section{The Movement to Open Hearings}

The first confirmation hearing of a Supreme Court nominee occurred in 1873, when the Committee held closed-door sessions on the nomination of George Williams to the position of Chief Justice. During these hearings, the Committee examined documents and took testimony from outside witnesses. The Committee's focus was narrow: it only examined evidence involving specific allegations that Williams used Department of Justice funds for household expenses. The Committee apparently was convinced that all was not as it should be, and Williams's nomination

4. This change was made as part of a postbellum general revision of Senate rules aimed at streamlining and clarifying the chamber's procedures, which included sending presidential nominations to the committee with jurisdiction over the nomination (Beth and Palmer 2011). The six exceptions were all former or current (at the time of their nomination) federal executive or legislative branch officials, who each enjoyed a smooth path to confirmation, reflecting the Senate's one-time deference to federal officeholders (Rutkus 2010). These nominees were Edwin Stanton (1869), Edward White (1894 as Associate Justice and 1910 as Chief Justice), William Howard Taft (1921), George Sutherland (1922), and James Byrnes (1941) (Rutkus and Bearden 2009). 
was subsequently withdrawn by President Grant (McFeely 1981, 391; Rutkus and Bearden 2009, 41).

The next hearings held by the Committee were on the nominations of Louis Brandeis in 1916 and Pierce Butler in 1922, both of whom were confirmed. The Brandeis hearing was significant, in that it marked the first time hearings were open to the public. It also was controversial, and attracted bitter opposition from conservatives fearful of Brandeis's reputation as "the people's lawyer," as well as from anti-Semites (Maltese 1995, 98; Abraham 2008, 141-44). Brandeis himself not only did not testify, but also refused to address the accusations made against him in any way (Abraham 2008, 143). The Butler hearings, in contrast, were held behind closed doors and again focused on a relatively narrow set of allegations; this time, that Butler acted in an unprofessional manner while serving on the University of Minnesota Board of Regents, and that he was biased toward railroad interests (Stras 2009). Like Brandeis, Butler did not testify in his own defense.

These early hearings thus differed from contemporary hearings in four significant ways. First, the hearings were reserved for allegedly controversial nominees. From 1873-1922, there were thirty-seven appointments to the Court, but only three hearings (Rutkus and Bearden 2009). Second, the hearings were limited in their scope, in that they focused predominately on the nominees' judicial temperaments and ethical standards, usually in the context of a particular accusation or scandal. Third, at none of these hearings did the nominees themselves testify. Instead, the hearings were limited to scrutinizing documents and taking testimony from witnesses other than the nominee (Rutkus and Bearden 2009). Fourth, two of the three hearings were held behind closed doors. Thus, the norm of holding open, public hearings featuring unrestricted nominee testimony was not yet established.

In 1925, Harlan Stone was the first nominee to testify before the Judiciary Committee. However, as with the three previous hearings, the purpose of his hearing was to deal with specific claims that he was unfit to serve on the high Court, rather than to engage the nominee in open-ended questioning about constitutional law. In particular, Stone testified at the urging of President Coolidge to answer a limited set of inquiries regarding his prosecution of individuals involved in the Teapot Dome affair during his tenure as attorney general. Stone's hearing was closed to the public and the questioning was restricted to his involvement in that scandal (Rutkus and Bearden 2009; Ringhand and Collins 2011). From 1925-1939, six other nominations were made to the Court, three of which featured confirmation hearings. At none of these hearings did the nominees testify (Rutkus and Bearden 2009).

In 1939, a major change to the Committee's role in the confirmation process was made when it initiated the practice of holding open public hearings for all Supreme Court nominees. Changes in the electorate, brought about by the enactment of the Seventeenth and Nineteenth Amendments, as well as the emergent civil rights movement, increasingly had required senators to expand their electoral appeal to a wider array of constituents (Egerton 1995, Part II; Maltese 1995, 37; Fischer 2011, Chapters 4 and 6). The Committee in 1939 also faced a more specific problem: the need to legitimize its work in light of its handling of the nomination of Hugo Black. 
Black was nominated by Franklin Delano Roosevelt in 1937 and was assured a speedy path to confirmation because he was a former senator. In fact, the Senate took just five days to confirm him and the Judiciary Committee did not hold public hearings on the nomination (Rutkus and Bearden 2009). After he was confirmed, Ray Sprigle of the Pittsburgh Post-Gazette revealed that, prior to his appointment, Black had accepted and apparently never relinquished a lifetime membership in the Ku Klux Klan (KKK) (Leuchtenburg 1973).

These allegations took the country by storm, with Sprigle winning a Pulitzer Prize for breaking the story (Newman 2003). Although the senators may or may not have understood the scope of Black's involvement with the Klan prior to their vote, the public perception was that the nomination was rushed through the Senate to avoid airing the issue in a public hearing. Belief in a cover-up was exacerbated when President Roosevelt broke tradition by having Black sworn in at a private ceremony at the White House, instead of at the customary public ceremony at the Supreme Court. In response to growing public outrage, Black discussed his affiliation with the KKK in a radio address in which he admitted belonging to the Klan as a young man and receiving an "unsolicited" lifetime membership, while also stating that he had resigned from the organization a decade before his appointment to the Court (New York Times 1937b).

Black unceremoniously took his seat on the bench just three days after his radio speech, but the damage to the Senate and the Judiciary Committee was done. The media and the public would seemingly no longer accept closed-door hearings ostensibly instituted to cover up a nominee's past indiscretions. Exemplifying this, the American Bar Association passed a resolution at its 1937 meeting petitioning the Senate to avoid difficulties like those raised by the Black situation by committing to holding public hearings on all future judicial nominations (New York Times 1937a).

The Judiciary Committee responded to these pressures, agreeing just two years later to hold open public hearings on the nomination of Felix Frankfurter. The Chair of the Judiciary Committee explicitly tied the decision to hold an open public hearing on the Frankfurter nomination to the Black debacle. "[I]n view of criticism of the Senate's speedy confirmation" of Justice Black, the Chair declared that the nomination of Felix Frankfurter would be "scrutinized thoroughly" before being approved by the Committee (New York Times 1939). At least one committee member, speaking at the opening of the Frankfurter hearing, tied this development to the desires for greater transparency and public input into the confirmation process. "[T]his is supposed to be a democratic form of government, and with respect to filling an office of great importance, if any citizens in good faith desire to be heard, I feel that it is our duty to hear them" (Frankfurter Transcript, opening statement by Senator King (D-UT) at 1. Source: Mersky and Jacobstein 1977).

Thus, the Judiciary Committee's impetus for holding public hearings was driven at least in part by the need to legitimize its actions to the public (Hall and Taylor 1996; Pierson 2000). The public, including investigative journalists, would now have a chance to observe the goings on in Judiciary Committee hearings and consequently put more direct electoral and interest group pressure on senators to support or oppose candidates to the high Court. In short, the Committee appears to 
have initiated the practice of holding public hearings as a means to help define and express its identity as a valid part of the democratic process (Hall and Taylor 1996, 949). ${ }^{5}$

\section{The Advent of Unrestricted Nominee Testimony}

In 1939, Felix Frankfurter became the first Supreme Court nominee to take virtually unrestricted questions in an open, transcribed hearing (Ringhand and Collins 2011). ${ }^{6}$ The next nominees to testify at the Committee hearings were Robert Jackson in 1941 and John Harlan in 1955. During this period (1939-1955), nine other nominations were referred to the Committee; at none of these hearings did the nominees testify (Rutkus and Bearden 2009).

It was not until 1955 that nominee testimony became customary. ${ }^{7}$ We posit that nominee testimony became the norm in 1955 for two interrelated reasons. First, this era marked the period in which the Court's salience in the US political system grew. Indeed, the modern era of the Supreme Court is typically identified as beginning in 1953 with the advent of the Warren Court (Segal and Spaeth 1993; Pacelle, Curry, and Marshall 2011), and it was in this era that the Court's involvement in highly salient civil rights and liberties policies increased in scope and visibility (McCloskey 1965). For example, the Warren Court handed down a higher percentage of decisions per term that appeared on the front page of the New York Times than its predecessor, the Vinson Court, as well as subsequent Courts (Epstein and Segal 2000, 74-75). Moreover, many of these decisions were met with political resistance, including congressional efforts to overturn them and limit the power of the Court (Nagel 1965), further elevating the Court into the national spotlight. Second, in 1954 the Court decided Brown v. Board of Education, and found itself at the forefront of US political debate. Given this, it should be no surprise that senators in this era were especially interested in examining nominees on their positions on that decision and the proper role of the Court in the political system (Yalof 2008; Farganis and Wedeking 2011; Collins and Ringhand 2013). In short, the Court's newfound prominence in US political debate likely motivated senators to examine potential members of the Court more rigorously, which was furthered by initiating the custom of nominee testimony.

The move to open testimony thus appears to have been made for primarily instrumental reasons. By compelling nominees to take unrestricted questions in

5. Note that opening the hearings to the public in 1939 corresponds to more general changes in Congress intended to promote legislative transparency. In particular, 1938 (a year after the Black hearing) marked the period in which documents from congressional committee hearings were made available to the public in federal depository libraries, although many of the depositories refused to accept hearing materials (Parrillo 2013, 323). However, it was not until 1946 that the Legislative Reorganization Act required that committee hearings be opened to the public (unless a committee voted against opening the hearings), indicating that the Judiciary Committee was an early adopter of open hearings.

6. The Committee continues to hold closed-door hearing sessions to question nominees regarding sensitive issues arising from the confidential investigations conducted by the Federal Bureau of Investigation and Committee staff (Collins and Ringhand 2013).

7. This year, 1955, also marked the first year that confirmation hearings were held before the entire Judiciary Committee. Prior to this date, hearings were held before a subcommittee (Yalof 2008, 146). 
public and under oath, Committee members both gather information about the type of justice the nominee is likely to be, and enjoy an opportunity to enhance their reelection prospects. This occurs in at least three ways. First, regularized nominee testimony provides Committee members with the ability to examine nominees on issues that may factor into their decisions to support or oppose a nominee, such as a nominee's positions on the pressing issues of the day and, more subtlety, the nominee's relative commitment to different legal doctrines and precedents (Collins and Ringhand 2013; Farganis and Wedeking 2014). Pressing the nominees on these issues gives the senators a forum to argue that certain decisions (most recently labeled "super precedents") should be considered settled and thus off the constitutional table. Seeing how nominees respond to such arguments, in public and under oath, provides unique information to the senators (Gerhardt 2006). Because the hearings take place in public during this era, senators' constituents also are able to follow the hearings, either directly or as mediated by interest groups and the media, thereby increasing the likelihood that senators will obtain better information about what their relevant constituencies think of the nominee (Farganis and Wedeking 2014).

Second, due to the public nature of the hearings, Committee members can utilize their allotted time to take positions, credit claim, and advertise (Mayhew 1974). Thus, even if a Committee member goes into the hearing knowing how he or she is going to vote on the nomination, the question and answer session still provides instrumental benefits (Watson and Stookey 1988). In position taking, Committee members can use the question and answer session to stake out their positions not just on the nominee, but also on other salient issues. By credit claiming, Committee members can highlight particular policies they want to advance, and demonstrate to their constituents that they are fulfilling their representational duties by relaying their constituents' concerns to potential members of the Supreme Court (Collins and Ringhand 2013). In addition, the substantial media attention devoted to confirmation hearings provides excellent opportunities for senators to advertise by increasing their visibility and appearance of importance through media coverage of the hearings, as well as through the issuance of press releases and other promotional materials highlighting the senators' advocacy.

Examples of position taking and credit claiming abound. Senatorial position taking on highly salient issues is a routine part of the hearings. For instance, consider Senator Ervin's (D-NC) comment at the Stewart hearing:

I think the Brown v. Board of Education was a most unfortunate decision from the standpoint of law, Constitutional law, in the United States. ... [T] he Court said that it couldn't turn the clock back to 1868 when the Amendment was ratified or even to 1896 when Plessy v. Ferguson was decided, and yet since Constitutional provisions are to be interpreted to ascertain and give effect to the intention of the people who drew them and approved them, that is exactly what the Supreme Court should have done. They should have turned the clock back to 1868 when the Amendment was ratified. (Stewart Transcript, questioning by Senator Ervin (D-NC) at 124. Source: Mersky and Jacobstein 1977) 
More recently, Senator Kohl (D-WI) took the opportunity at Samuel Alito's confirmation hearing to position take: "In my view, one of the most important pieces of social legislation enacted in the last two decades was the Family and Medical Leave Act in 1993" (Alito Transcript, questioning by Senator Kohl (D-WI) at 384. Source: US Senate 2012). Similarly, Senator Leahy (D-VT) used the hearing of Elena Kagan to take a position important to his constituents: "Two years ago, in the District of Columbia v. Heller, the Supreme Court held the Second Amendment guarantees to an American's individual right to keep and bear arms. I'm-I'm a gun-owner, as are many people in Vermont, and I agreed with the Heller decision" (Kagan Transcript, questioning by Senator Leahy (D-VT) at 6. Source: Washington Post 2010a).

Credit claiming also is a frequent occurrence at the hearings. Two examples from Ruth Bader Ginsburg's hearing illustrate how Committee members credit claim at the hearings:

Senator Kennedy: As someone who is a sponsor of that Fair Housing Act, along with others on this committee, I was struck by the appreciation that you showed in your opinion for the need for private enforcement actions against this kind in discrimination. (Ginsburg Transcript, questioning by Senator Kennedy (D-MA) at 139. Source: US Senate 2012)

Senator Pressler: In the 1970's, when I was a member of the House, I was quoted by the Supreme Court, albeit in a footnote, because they wanted some legislative history. I had helped the Sioux Tribes by working for legislation that allowed them to go back into court enabling them to file suit in the Court of Claims for compensation for the Black Hills of South Dakota. (Ginsburg Transcript, questioning by Senator Pressler (R-SD) at 237. Source: US Senate 2012)

Likewise, since Supreme Court confirmation hearings are highly salient events, the appearance of senators at the hearings raises their profile in the public eye, allowing them to advertise. There is strong evidence that the public pays attention to the hearings (Gimpel and Wolpert 1996; Gibson and Caldeira 2009, 71). For example, Farganis and Wedeking $(2014,100)$ report that millions of Americans tuned into live coverage of the Sotomayor hearing, and many more obtained information about the hearings from television newscasts and newspapers as the hearings are featured broadly throughout the media (Bybee 2011). Still another source of information about the hearings comes from interest groups, who use the hearings in their advertising efforts. For example, Vining (2011) reveals that ten organizations reached millions of Americans in dozens of e-mail messages timed to coincide with the Roberts and Alito hearings. Moreover, Judiciary Committee members also promote their involvement in confirmation hearings on their Web pages, indicating that they are eager for their constituents to see and appreciate their role in the process. ${ }^{8}$

8. For recent examples of this, see www.leahy.senate.gov and www.grassley.senate.gov (accessed July 9, 2014). 


\section{CHANGES IN THE NATURE AND CONTENT OF CONFIRMATION DIALOGUE}

To examine the second type of change seen in the confirmation process-the changing nature and content of confirmation dialogue-we rely on an original database of confirmation hearing discourse. This dataset contains information on every Supreme Court nominee who took unrestricted questions before the Judiciary Committee from 1939-2010 and is based on the transcripts of the hearings. ${ }^{9}$ The unit of analysis in the database is the change of speaker, meaning that a new observation begins whenever the speaker changes (e.g., from senator to nominee). We coded a host of variables for each statement, including the senator asking the question, the senator's political party, whether or not the question or comment involved the discussion of a judicial decision, and the issue and subissue areas involved in each statement. To code the issue and subissue variables, we relied on the categories used in the Policy Agendas Project (Baumgartner and Jones 2013), with the addition of several hearing-specific issue areas. ${ }^{10}$ Intercoder agreement tests reveal that the data are very reliable. ${ }^{11}$

For senators to use the hearings to improve the quality of the information available to them, nominee testimony must provide senators with substantive answers to their questions. Though some accounts of the hearings have asserted that nominees rarely say anything of value (Reynolds 1992; Yalof 2008), more recent studies show that nominee evasiveness is infrequent, and that there has been no decrease in nominee candor over time. For example, Farganis and Wedeking (2011, 540-42) demonstrate that the vast majority of answers provided by nominees from 1955-2010 were "fully forthcoming" and that there has been no steep decline in nominee candor since the 1980s (see also Wedeking and Farganis 2010; Farganis and Wedeking 2014). Similarly, Collins and Ringhand (2013) find that nominees testifying from 1939-2010 outright refused to answer senators' questions less than 5 percent of the time and that there was no increase in nominee evasiveness over time.

9. The transcripts come from the following sources: Frankfurter to Blackmun: Mersky and Jacobstein (1977); Powell to Alito: US Senate (2012); Bork: Library of Congress (2012); Sotomayor: New York Times (2009a, 2009b, 2009c); Kagan: Washington Post (2010a, 2010b). We excluded the portion of the Clarence Thomas hearing that was devoted to questions regarding allegations of sexual harassment brought by Anita Hill since that aspect of the hearing was focused solely on those allegations and thus did not involve unrestricted questioning (Yalof 2008, 163).

10. The topics adopted from the Policy Agendas Project include macroeconomics; civil rights; health; agriculture; labor and employment; education; environment; energy; transportation; law, crime, and family; social welfare; community development and housing; banking, finance, and domestic commerce; defense; space, technology, and communications; foreign trade; international affairs and aid; government operations; public land and public water; state and local government; weather; fires; arts and entertainment; sports and recreation; death notices; and churches and religion. We added the following categories: federalism; court administration; statutory interpretation; best/favorite justices; best/favorite cases or opinions; worst cases or opinions; standing/access to courts; nonstanding justiciability issues; judicial philosophy; hearing administration; nominee background; media coverage of the hearing; and prehearing conversations/coaching.

11. To verify the reliability of the data, we extracted a random sample of 740 observations (2.4 percent of the data), which gives us precision of \pm 3.6 percent with 95 percent confidence. The mean intercoder agreement rate for variables used in this article is 96.8 percent and the average kappa value is 0.936 , which is considered "almost perfect" by one commonly used metric (Landes and Koch 1977, 165). 


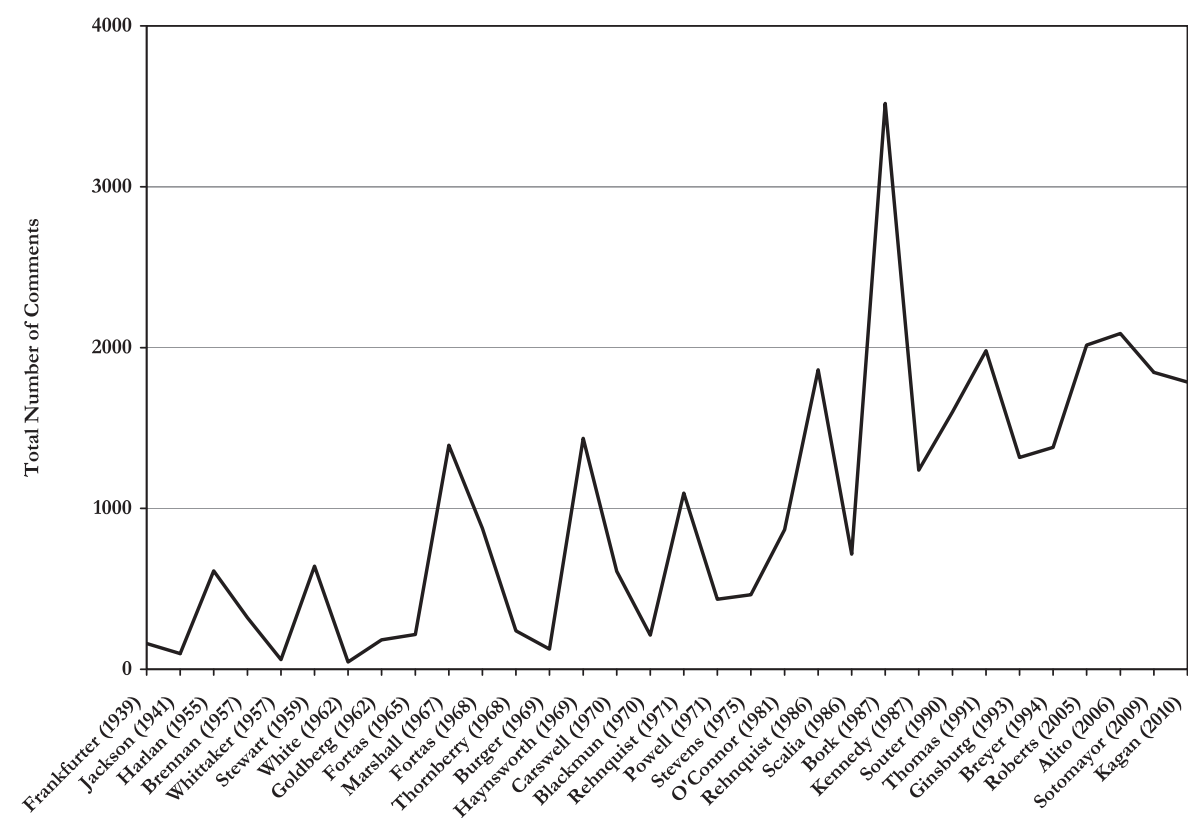

FIGURE 1.

The Number of Comments Made at Supreme Court Confirmation Hearings, 1939-2010

Thus, it is clear that senators are capable of using the hearings to extract meaningful answers from the nominees. The reminder of this section explores how those answers have changed over time, in ways that promote both the senators' legitimating and instrumental goals. Grounding analysis in data derived from the original dataset described above allows us to show more clearly both the nature of these changes and how they were likely influenced by both endogenous and exogenous factors.

\section{Increase in the Number of Confirmation Comments}

We begin our investigation into changes in the Committee's scrutiny of nominees by examining the number of comments made at each hearing, which is reported in Figure $1 .^{12}$ Nominees appear along the $\mathrm{x}$-axis, while the total number of statements made at each hearing constitutes the y-axis. As this figure makes evident, there was a relatively steady increase in hearing discourse during the first five decades of hearings, a sharp increase in the mid-1980s, then a period of relative stabilization that continues to this day. During the 1930s and 1940s, an average of 129 comments

12. The Appendix contains the results of Poisson and Tobit models corresponding to Figures 1-4 that corroborate the significance of the events discussed in the context of these figures on the development of the hearings. 
were made at each hearing. This increased to 409 in the 1950s and about 560 in the 1960s and 1970s. There was a large increase in hearing dialogue in the 1980s, with an average of 1,640 comments per hearing, followed by a period of stabilization. In the 1990s, the average number of hearing comments was 1,569 , while the average for the 2000s was 1,934. ${ }^{13}$ Thus, insofar as the number of comments at each hearing "signals the degree of inspection applied to each potential judge" (Dancey, Nelson, and Ringsmuth 2011, 129), it is clear that the Judiciary Committee has substantially increased its scrutiny of Supreme Court nominees over time. ${ }^{14}$

Below, we investigate in greater detail how the expanded scope of the hearings contributed to the increase in the number of comments made at the hearings into the 1980s. Here we explain the increase in the quantity of hearing dialogue in the 1980s. This development correlates with the introduction of gavel-to-gavel television coverage of the hearings. In 1981, C-SPAN first televised the hearings, and coverage was expanded to public television in 1986 and to CNN and other cable networks in 1987 (Comiskey 1999, 33; Farganis and Wedeking 2011, 531). In the decade preceding O'Connor's 1981 appearance before the Committee, an average of 664 statements were made at the hearings. During the O'Connor hearing, 868 statements were made. Post-O'Connor, on average, 1,779 comments were made at the hearings. ${ }^{15}$

Thus, although O'Connor's was the first televised hearing, the most significant increase in hearing dialogue began with the subsequent hearing-that of William Rehnquist in 1986 for the Chief Justice position. It therefore appears that the O'Connor hearing taught Committee members that the expanded broadcast of the hearings provided senators increased opportunities to use them in new ways. Even though it was unlikely that most Americans would tune into the hearings for hours on end, broadcasting the hearings provided the public with the option of watching portions of the hearings live or catching recaps on nightly news. ${ }^{16}$ As a result, for the first time, Americans could watch and listen to Committee members probe

13. The sharp increase in hearing comments in the $1980 \mathrm{~s}$ is statistically significant relative to earlier eras $(t=3.68, p=0.001)$. The slight decrease in hearing discourse in the 1990 s is not a statistically significant drop relative to the amount of dialogue in the 1980s and 2000s $(t=0.466, p=0.651)$.

14. These results hold if we separate statements made by nominees and senators: the correlation between the number of comments made by senators and nominees is 0.99 . In addition, we obtain consistent results if we exclude nonsubstantive comments having to do with hearing administration and social chitchat from the overall number of hearing statements.

15. This figure drops to 1,620 comments when we exclude the Bork hearing, which is a clear outlier. We verified that the increase in hearing dialogue came immediately after the O'Connor hearing by running a Poisson regression model using the total number of comments as the dependent variable, with independent variables capturing the Rehnquist and Bork hearings and the year of the hearing. This corroborated that the increase in hearing dialogue is attributable primarily to Rehnquist's Chief Justice hearing in 1986 (the first post-O'Connor hearing) as the coefficient associated with the Rehnquist hearing is 50 percent larger than the coefficient associated with the Bork hearing. This finding also suggests that the increase in hearing dialogue is primarily attributable to television coverage, and not to the fact that the Bork hearing marked the first time that nominees faced questions from all members of the Judiciary Committee (Wedeking and Farganis 2010).

16. Public interest in televised congressional committee hearings was largely initiated with the Watergate hearings in 1973, which drew major audiences (Robinson 1974). With the exception of particularly controversial hearings (e.g., Thomas), television viewership of confirmation hearings is much lower than such high-profile events as the investigation of alleged criminal conduct in the executive branch that occurred during Watergate (Kurtz 2009). Nonetheless, millions of Americans tune into the hearings (Farganis and Wedeking 2014, 100). 
nominees on the salient issues of the day. ${ }^{17}$ Senators seemed to have recognized that televising the hearings provided them with a wider audience and an enhanced ability to use the hearings as an opportunity to take public positions, claim credit, and advertise (see also Yalof 2008). Consequently, televising the hearings contributed to the increased scrutiny of Supreme Court nominees, which promoted the ability of Committee members to pursue electoral goals. ${ }^{18}$

\section{Changes in the Content of Hearing Discourse}

This increased scrutiny, moreover, is substantive, not superficial. It is due to a reduction in nonsubstantive dialogue, combined with increased attention to judicial decisions and an expansion in the scope of issues discussed at the hearings. As we show below, the hearings were initially quite short and often chummy affairs. In the late-1960s through the mid-1970s, they turned into more serious discussions as Committee members began examining nominees on their views of judicial decisions and increased the breadth of their questions. Perhaps more than anything else, these developments helped define the unique role, and unique value, of the Judiciary Committee, enabling senators both to enhance the legitimacy of the hearings and to pursue instrumental goals, while further differentiating the Committee from other actors in the confirmation process.

Although Supreme Court confirmations have long been subject to political conflicts (Epstein and Segal 2005; Abraham 2008), prior to Thurgood Marshall's appearance before the Committee in 1967, the hearings at which the nominees themselves appeared tended to be brief and were usually nonconfrontational (Yalof 2008). ${ }^{19}$ From 1939-1965, an average of only 260 comments were made at the hearings. From Marshall to O'Connor, this increased to 1,074 statements per hearing (and to 1,778 in the post-O'Connor era). Importantly, the qualitative content of hearing discourse during this time period changed in three notable ways. First, senators moved away from devoting a substantial amount of their "questions" to expressing their admiration for the nominees and engaging in nonsubstantive dialogue. For example, at Charles Whittaker's hearing in 1957, more than a third of questions involved basic background information, such as where the nominee was born, went to school, and his family status. Senator Watkins (R-UT) went as far as to praise Whittaker for his persistency for having ridden a pony to and from school

17. Americans' ability to view the hearings was further increased in 2005 when confirmation hearing videos were first posted to the Internet (C-SPAN 2005), allowing the public to access both edited and unedited videos of the hearings at their convenience.

18. To verify this conclusion further, we investigated whether televising the hearings had an independent effect on the number of statements made at the hearings after controlling for the increased polarization in the Senate that took place during the time period under investigation and conditions of divided government. Employing Poole's (2013) measure of polarization, we continue to find evidence that the postO'Connor era marked an increase in hearing dialogue. These results appear in the Appendix. In addition, we investigated whether the Court's level of activism shapes hearing comments (Silverstein 1994) from 1955-2010. We found that hearing dialogue is positively influenced by the Court's level of judicial activism (measured by the percentage of cases overturning local, state, or federal laws), although the strength of this effect is not nearly as strong as the introduction of televised coverage of the hearings (results not shown).

19. The confirmation hearing of Felix Frankfurter (1939) was a notable exception. 


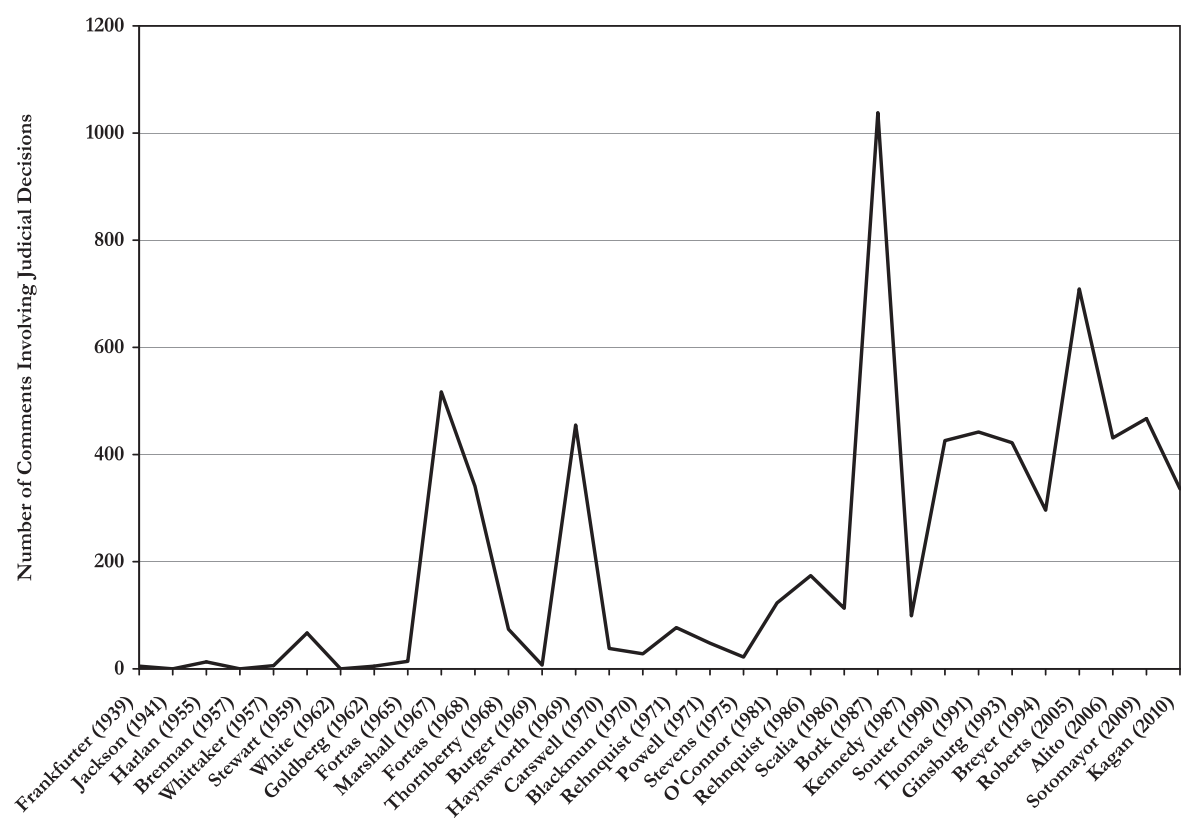

FIGURE 2.

The Number of Comments Made at Supreme Court Confirmation Hearings Devoted to Judicial Decisions, 1939-2010

each day. Likewise, during the hearing of Byron White in 1962, a full third of the hearing was devoted to the senators gushing about White's athletic prowess (he was a former professional football player). While it was not uncommon for Committee members to express their esteem for later nominees and engage them in congenial questioning, the senators no longer devote such substantial portions of the hearings to doing so.

Instead, a large proportion of hearing inquiries today are dedicated to examining nominees on their perspectives on particular judicial decisions, the second notable development we identify. Figure 2 illustrates this by reporting the number of comments at each hearing involving judicial decisions. ${ }^{20}$ Discussions of precedent were rare at the earliest hearings: an average of only twelve comments at hearings prior to 1967 involved questioning nominees on judicial decisions and precedents were never broached at three hearings, those of Jackson, Brennan, and White. Beginning with Marshall's appearance, however, debates about precedent became a

20. We coded all instances in which a statement unambiguously related to a named case as involving the discussion of a judicial decision, even if the senator or nominee did not identify the case in a given comment. For example, if a senator asked a nominee about his or her position on a case and the nominee provided that position without referencing the case, both statements are coded to reflect the fact that they implicated a judicial decision. Though we focus on the number of comments related to judicial decisions in Figure 2, we also observe an increase over time in the percentage of comments discussing judicial decisions, thus indicating that the rise in attention to judicial decisions is not merely a function of the increase in overall hearing discourse. 


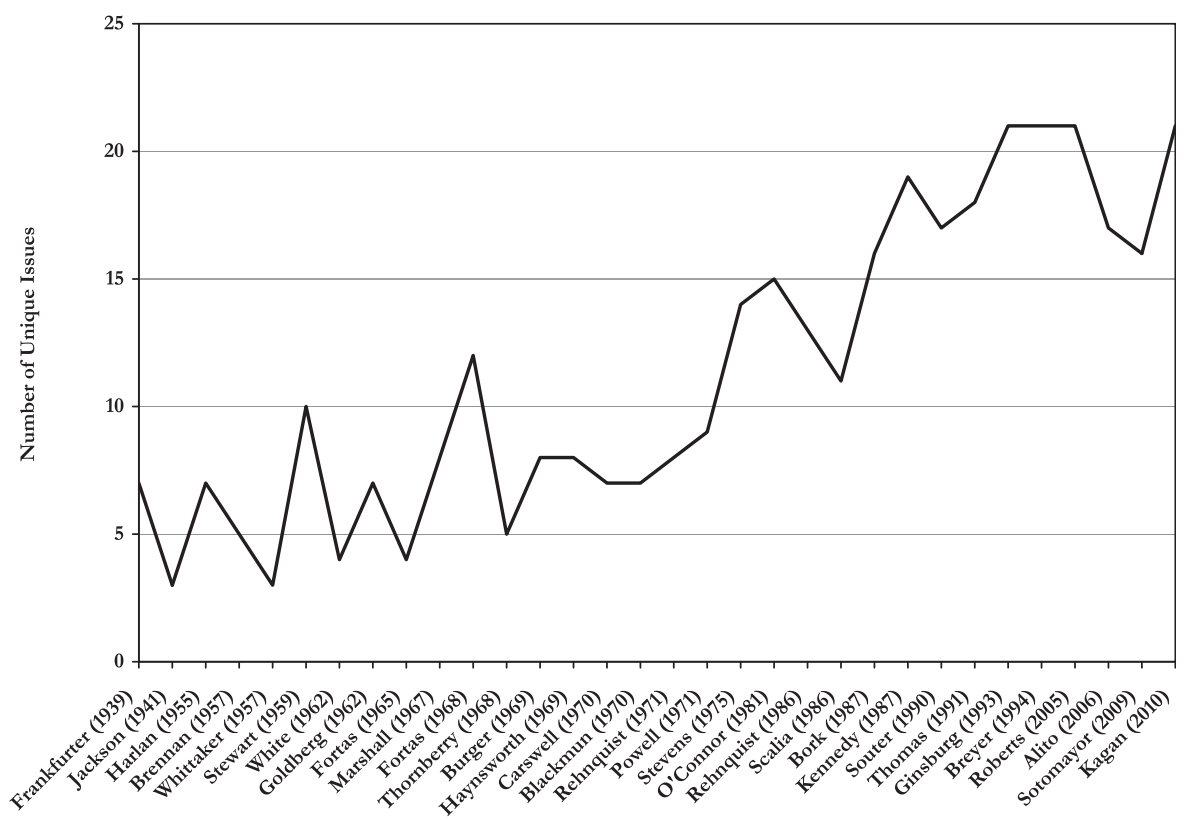

FIGURE 3.

The Number of Unique Issues Addressed at Supreme Court Confirmation Hearings, 1939-2010

mainstay at the hearings: from 1967-2010, an average of 291 comments implicated the nominees' views of judicial decisions. Though there is some notable variability in this figure, with modest attention devoted to precedent at the Burger hearing in 1969 and those held in the 1970s, the Marshall hearing nonetheless ushered in a new age in hearing content (Batta et al. 2012).

In Marshall's hearing, much of this discussion involved southern senators questioning Marshall on his opinions of Warren Court decisions, such as Escobedo v. Illinois (1964) and Miranda v. Arizona (1966), that they saw as an overreach of the Supreme Court's authority. ${ }^{21}$ Thus, the growing salience of the Court in the 1950s, which contributed to the move to unrestricted public testimony, was also reflected in later hearings that involved the senators interrogating nominees on Warren Court precedents. In subsequent hearings, precedent-based questioning continued as senators grew comfortable with using the hearings not just to query nominees on the pressing constitutional questions of the day, but to do so in the specific language of the Court's own precedents.

The third change in the content of hearing dialogue we explore involves the range of issues discussed at the hearings. This information appears in Figure 3, which reports the total number of unique issues addressed at each hearing based on the thirty-nine categories discussed in footnote ten. This figure reveals a rather steady

21. By Marshall's hearing, senators were no longer willing to challenge the Brown decision directly, but much of the questioning of Marshall, who led the legal challenge in Brown, clearly implicated that case (Collins and Ringhand 2013, 167). 
increase in terms of the diversity of hearing discourse over time. With the exceptions of Fortas (1968) and Stewart (1959), all the hearings prior to 1975 involved the discussion of less than ten issues. From 1975-2010, an average of seventeen issues were addressed at each hearing. Thus, the Stevens hearing marked a change in the substance of the hearings, as is evidenced by the sharp increase in the number of issues discussed at each hearing beginning in 1975. As Ringhand and Collins (2011) demonstrate, much of the change in the focus of hearing dialogue involved increased attention to issues that gained particular salience beginning in the 1960s and 1970s, most notably racial and gender discrimination. It is apparent that the senators responded to the expansion of the political community to include minorities and women by investigating nominees' positions on issues salient to these groups. This finding is consistent with Cameron, Kastellec, and Park's (2013) evidence that, beginning in the 1970s, senators' support for nominees began to be influenced by a wider range of issues than in the past. Thus, not only are contemporary senators asking about a wider range of issues, but these diverse topics also are influencing their voting behavior.

We attribute the three changes identified above to both fostering the legitimacy of the hearings and enhancing the ability of Committee members to pursue instrumental goals. Transitioning the hearings from chummy affairs among friends to forums in which nominees are pressed on their views on Supreme Court precedent and salient legal and political issues promoted the social acceptance of the hearings to an expanding citizenry. It did this by helping to establish the hearings as important democratic checks on the makeup of the Supreme Court. While many early nominees were able to win confirmation by currying favor with senatorial "insiders," for later nominees the hearings are a moment of democratic reckoning. Responding to the concerns of an expanding electorate, nominees today are expected to provide their perspectives on a wide range of significant issues and affirm the existing constitutional consensus before taking their seats on the high Court (Collins and Ringhand 2013). Thus, the transformation of the content of hearing dialogue helped establish the hearings as having a unique and significant role in the Supreme Court confirmation process.

At the same time, these changes allowed Committee members to pursue instrumental goals. First, the growing substance and gravity of nominee questioning better enabled senators to make informed choices as to whether to support or oppose a nominee's candidacy for the Court. Second, the move away from devoting significant attention to nonsubstantive questioning to primarily debating salient legal and political issues, including the Court's precedents, provided a high-profile forum for Committee members to engage in position taking and advertising on issues that are important to their constituents (a role that was made even more visible after the hearings were televised in 1981). Finally, diversifying the range of topics discussed at the hearings increased the opportunities for senators to claim credit for their own contributions to the development of the policies debated at the hearings.

\section{Equalizing Questioning}

The final institutional development we explore involves the equalization of nominee questioning between Committee members of both parties. Figure 4 reports 


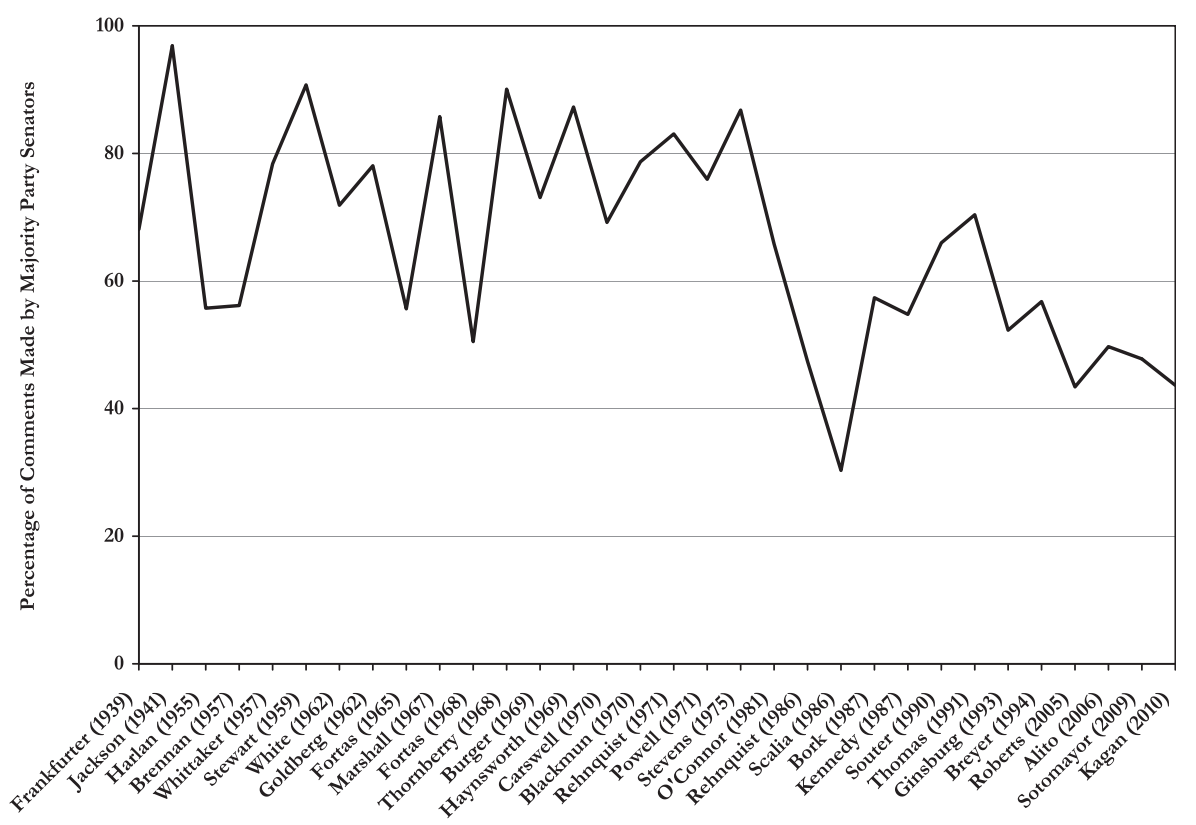

\section{FIGURE 4.}

The Percentage of Comments Made by Majority Party Senators at Supreme Court Confirmation Hearings, 1939-2010

the percentage of comments made by majority party senators. During the first four decades of hearings, there was substantial imbalance in the number of statements made by majority and minority party senators. From 1939-1975, Democrats, who were in control of the Judiciary Committee, contributed 75 percent of all hearing dialogue. Beginning with the O'Connor hearing, however, dialogue evened out. From 1981-2010, questions made by majority party senators accounted for 53 percent of all hearing dialogue. Thus, the past three decades of hearings have been defined by a move toward equality in nominee questioning (see also Farganis and Wedeking 2011), as is evidenced by the decrease in the percentage of majority party comments since the 1970s.

Differences in questioning based on partisanship are, of course, partly attributable to the makeup of the Committee. As would be expected, during periods of Democratic control of the Committee, Democratic senators have more members and tend to ask more questions. As the size of the majority party's dominance in the Senate decreased over time, more minority party members joined the Committee, resulting in an equalization of questioning. Thus, the move toward equity in questioning is due in part to changes in the distribution of committee assignments in the Senate. As Sinclair (1988) notes, the 1980s marked a period in which committee assignments were distributed more evenly between the Democratic and Republican parties as senators took up more committee positions. As it pertains to the Judiciary Committee, a consequence of this is that we would expect to see less 
one-party dominance of the hearings beginning in the 1980s, which is borne out in Figure 4 .

We concur with Sinclair (1988) that increased equity in Committee assignments between the political parties, a consequence of which was the equalization of hearing questioning, was pursued for primarily instrumental reasons. Distributing committee assignments more evenly allowed senators from both parties to take advantage of the benefits that can accrue from their participation in confirmation hearings. Namely, a wider range of senators were enabled to engage nominees, allowing them to make better informed choices regarding their confirmation votes and use the hearings to position take, credit claim, and advertise.

\section{CONCLUSIONS}

The most frequently told narrative of institutional change regarding the confirmation hearings held by the Senate Judiciary Committee has been one of a relatively static process that has changed (for the worse) only relatively recently and in response to a few high-profile events, such as the failed 1987 hearing of Robert Bork or the increase in political polarization seen in recent decades (Carter 1994; Eisgruber 2007; Dworkin 2009). In this article, we have rebutted that view by presenting a comprehensive analysis of the institutionalization of the Senate Judiciary Committee hearings of Supreme Court nominees. ${ }^{22}$ As we have illustrated, the process has been marked by incremental and multifaceted change. What began as a largely nondescript committee with only limited input into the fate of Supreme Court nominees developed into a highly visible institution that plays a starring role in the confirmation process.

We further explored the likely reasons behind these changes, demonstrating that both legitimating and instrumental factors contributed to the evolution of the Committee's role. For example, the Committee responded to public outrage about its handling of the Black nomination with the legitimacy-enhancing move of beginning to hold open, public hearings in 1939. Other developments, however, occurred for primarily instrumental reasons, such as the increase in hearing dialogue that occurred in the mid-1980s following the inaugural television broadcast of the hearings in 1981. Senators took advantage of the opportunity television coverage provided to use the hearings to communicate with their constituents, thereby increasing their opportunities to credit claim, position take, and advertise. Still other changes were motivated by both legitimizing and instrumental factors, such as the evolution of the content of hearing discourse in the 1960s and 1970s.

While we have framed our analysis of the institutionalization of Supreme Court confirmation hearings in terms of how developments promoted the legitimacy of the hearings and members' instrumental goals, this article also sheds light on

22. While we have explored a range of institutional developments, we have focused on major changes to the confirmation hearings, as opposed to more minor alterations such as setting aside a portion of the hearings for closed-door sessions regarding the confidential investigations of the nominees conducted by the FBI that began in 1992 (Rutkus 2010). In addition, we have omitted developments exogenous to the Committee, including the increasing use of "murder boards" to prepare nominees for their hearings (Rutkus 2010). 


\section{LAW \& SOCIAL INQUIRY}

whether endogenous or exogenous factors shape institutional change (March and Olsen 1984). We believe three changes are best viewed as being primarily motivated by exogenous events. First, public indignation at the Committee's handling of the Black nomination accelerated the opening up of the process and the regularization of nominee testimony. Second, the introduction of live television coverage of the hearings contributed to the increase in senatorial questioning. Third, the equalization of questioning between members of both political parties is due principally to broader changes in the Senate as a whole, including the weakening grasp of the Democratic Party and the more equitable distribution of committee assignments. The proximate cause of other changes we have identified, such as the alterations in the content of hearing discourse, appear to have both endogenous and exogenous roots. For example, while senators themselves increased the breadth and substance of their questioning to promote instrumental goals, they did so in part to demonstrate they were responsive to the concerns of an expanding electorate.

This research corroborates the utility of viewing institutional development from both legitimating and instrumental perspectives (Hall and Taylor 1996; Pierson 2000). As institutions evolve, they establish norms that help them carve out their identities as legitimate parts of the governing system. In the process, actors are able to utilize these changes to advance their own goals. Thus, studying institutional change enhances our understanding of both the political system at large and the behavior of actors in that system.

\section{REFERENCES}

Abraham, Henry J. 2008. Justices, Presidents, and Senators: A History of U.S. Supreme Court Appointments from Washington to Bush II. Lanham, MD: Rowman \& Littlefield.

Batta, Anna, Paul M. Collins, Jr., Tom Miles, and Lori A. Ringhand. 2012. Let's Talk: Judicial Decisions at Supreme Court Confirmation Hearings. Judicature 96 (1): 7-15.

Baumgartner, Frank, and Bryan Jones. 2013. Policy Agendas Project. http://www.policyagendas.org (accessed January 15, 2013).

Beth, Richard S., and Betsy Palmer. 2011. Supreme Court Nominations: Senate Floor Procedure and Practice, 1789-2011. CRS Report for Congress, March 11.

Bybee, Keith. 2011. Will the Real Elena Kagan Please Stand Up? Conflicting Public Images in the Supreme Court Confirmation Process. Wake Forest Journal of Law $\mathcal{E}$ Policy 1 (1): 13755.

C-SPAN. 2005. Homepage. https://web.archive.org/web/20050913183339/http:/www.c-span.org/ (accessed November 6, 2014).

Cameron, Charles M., Jonathan P. Kastellec, and Jee-Kwang Park. 2013. Voting for Justices: Change and Continuity in Confirmation Voting, 1937-2010. Journal of Politics 75 (2): 28399.

Carter, Stephen L. 1994. The Confirmation Mess: Cleaning Up the Federal Appointments Process. New York: Basic Books.

Collins, Paul M., Jr., and Lori A. Ringhand. 2013. Supreme Court Confirmation Hearings and Constitutional Change. New York: Cambridge University Press.

Comiskey, Michael. 1999. Not Guilty: The News Media in the Supreme Court Confirmation Process. Journal of Law \& Politics 15 (1): 1-36.

Crowe, Justin. 2012. Building the Judiciary: Law, Courts, and the Politics of Institutional Development. Princeton, NJ: Princeton University Press. 
Dancey, Logan, Kjersten R. Nelson, and Eve M. Ringsmuth. 2011. "Strict Scrutiny?" The Content of Senate Judicial Confirmation Hearings During the George W. Bush Administration. Judicature 95 (3): 126-35.

Dworkin, Ronald. 2009. Justice Sotomayor: The Unjust Hearings. New York Review of Books, September 24.

Egerton, John. 1995. Speak Now Against the Day: The Generation Before the Civil Rights Movement in the South. New York: Alfred A. Knopf.

Eisgruber, Christopher L. 2007. The Next Justice: Repairing the Supreme Court Appointments Process. Princeton, NJ: Princeton University Press.

Epstein, Lee, and Jeffrey A. Segal. 2000. Measuring Issue Salience. American Journal of Political Science 44 (1): 66-83.

2005. Advice and Consent: The Politics of Judicial Appointments. New York: Oxford University Press.

Farganis, Dion, and Justin Wedeking. 2011. "No Hints, No Forecasts, No Previews": An Empirical Analysis of Supreme Court Nominee Candor from Harlan to Kagan. Law $\mathcal{E}$ Society Review 45 (3): 525-59.

- 2014. Supreme Court Confirmation Hearings in the U.S. Senate: Reconsidering the Charade. Ann Arbor, MI: University of Michigan Press.

Fenno, Richard F., Jr. 1962. The House Appropriations Committee as a Political System: The Problem of Integration. American Political Science Review 56 (2): 310-24.

Fischer, Claude S. 2011. Made in America: A Social History of American Culture and Character. Chicago, IL: University of Chicago Press.

Gamm, Gerald, and Kenneth Shepsle. 1989. Emergence of Legislative Institutions: Standing Committees in the House and Senate, 1810-1825. Legislative Studies Quarterly 14 (1): 39-66.

Gerhardt, Michael J. 2006. Super Precedent. Minnesota Law Review 90 (5): 1204-31.

Gibson, James L., and Gregory A. Caldeira. 2009. Citizens, Courts, and Confirmations. Princeton, NJ: Princeton University Press.

Gimpel, James G., and Robin M. Wolpert. 1996. Opinion-Holding and Public Attitudes Toward Controversial Supreme Court Nominees. Political Research Quarterly 49 (1): 163-76.

Goldman, Sheldon. 1997. Picking Federal Judges: Lower Court Selection from Roosevelt Through Reagan. New Haven, CT: Yale University Press.

Hall, Peter A., and Rosemary C. R. Taylor. 1996. Political Science and the Three New Institutionalisms. Political Studies 44 (5): 936-57.

Hibbing, John R. 1988. Legislative Institutionalization with Illustrations from the British House of Commons. American Journal of Political Science 32 (3): 681-712.

Huntington, Samuel P. 1965. Political Development and Political Decay. World Politics 17 (3): $386-430$.

Kurtz, Howard. 2009. Sotomayor Hearings Fail to Excite Adrenaline-Fueled Media. Washington Post, July 20.

Library of Congress. 2012. Supreme Court Nominations-Not Confirmed or Withdrawn. http:// www.loc.gov/law/find/court-withdrawn.php (accessed September 6, 2012).

Leuchtenburg, William E. 1973. A Klansman Joins the Court: The Appointment of Hugo L. Black. University of Chicago Law Review 41 (1): 1-31.

Maltese, John Anthony. 1995. The Selling of Supreme Court Nominees. Baltimore, MD: Johns Hopkins University Press.

March, James G., and Johan P. Olsen. 1984. The New Institutionalism: Organizational Factors in Political Life. American Political Science Review 78 (3): 734-49.

Mayhew, David. 1974. Congress: The Electoral Connection. New Haven, CT: Yale University Press.

McCloskey, Robert G. 1965. Reflections on the Warren Court. Virginia Law Review 51 (7): 1229_ 70.

McFeely, William S. 1981. Grant: A Biography. New York: W. W. Norton \& Company.

McGuire, Kevin T. 2004. The Institutionalization of the U.S. Supreme Court. Political Analysis 12 (2): $128-42$. 
Mersky, Roy M., and J. Myron Jacobstein, eds. 1977. The Supreme Court of the United States: Hearings and Reports on Successful and Unsuccessful Nominations of Supreme Court Justices by the Senate Judiciary Committee, 1916-1975. Buffalo, NY: William S. Hein.

Meyer, John W., and Brian Rowan. 1977. Institutionalized Organizations: Formal Structure as Myth and Ceremony. American Journal of Sociology 83 (2): 340-63.

Nagel, Stuart S. 1965. Court-Curbing Periods in American History. Vanderbilt Law Review 18 (3): 925-44.

Newman, Roger K. 2003, Hugo Black: A Biography. New York: Fordham University Press.

New York Times. 1937a. Bar Asks Inquires on Future Judges. New York Times, October 2.

- 1937b. Radio Talk Is Brief. New York Times, October 2.

1939. Hearings Are Set on Frankfurter. New York Times, January 8.

- 2009a. Sotomayor Confirmation Hearings, Day 2. http://www.nytimes.com/2009/07/14/us/ politics/14confirm-text.html?_r=1\&pagewanted=all (accessed September 6, 2012).

—. 2009b. Sotomayor Confirmation Hearings, Day 3. http://www.nytimes.com/2009/07/15/us/ politics/15confirm-text.html?pagewanted=all (accessed September 6, 2012).

—. 2009c. Sotomayor Confirmation Hearings, Day 4. http://www.nytimes.com/2009/07/16/us/ politics/16confirm-text.html?pagewanted=all (accessed September 6, 2012).

Pacelle, Richard L., Jr., Brett W. Curry, and Bryan W. Marshall. 2011. Decision Making by the Modern Supreme Court. New York: Cambridge University Press.

Parrillo, Nicholas R. 2013. Leviathan and Interpretive Revolution: The Administrative State, the Judiciary, and the Rise of Legislative History, 1890-1950. Yale Law Journal 123 (2): 266529.

Pierson, Paul. 2000. The Limits of Design: Explaining Institutional Origins and Change. Governance: An International Journal of Policy and Administration 13 (4): 475-99.

Polsby, Nelson. 1968. The Institutionalization of the U.S. House of Representatives. American Political Science Review 62 (1): 144-68.

Poole, Keith. 2013. The Polarization of the Congressional Parties. http://voteview.com/political_ polarization.asp (accessed May 8, 2013).

Ragsdale, Lyn, and John J. Theis, III. 1997. The Institutionalization of the American Presidency, 1924-92. American Journal of Political Science 41 (4): 1280-1318.

Reynolds, Glenn Harlan. 1992. Taking Advice Seriously: An Immodest Proposal for Reforming the Confirmation Process Southern California Law Review 65 (March): 1572-82.

Ringhand, Lori A., and Paul M. Collins, Jr. 2011. May it Please the Senate: An Empirical Analysis of the Senate Judiciary Committee Hearings of Supreme Court Nominees, 19392009. American University Law Review 60 (3): 589-641.

Robinson, Michael J. 1974. The Impact of the Televised Watergate Hearings. Journal of Communication 24 (2): 17-30.

Rutkus, Denis Steven. 2010. Supreme Court Appointment Process: Roles of the President, Judiciary Committee, and Senate. CRS Report for Congress, February 19.

Rutkus, Denis Steven, and Maureen Bearden. 2009. Supreme Court Nominations, 1789-2009: Actions by the Senate, the Judiciary Committee, and the President. CRS Report for Congress, May 13.

Segal, Jeffrey A., and Albert D. Cover. 1989. Ideological Values and the Votes of U.S. Supreme Court Justices. American Political Science Review 83 (2): 557-65.

Segal, Jeffrey A., and Harold J. Spaeth. 1993. The Supreme Court and the Attitudinal Model. New York: Cambridge University Press.

Selznick, Philip. 1957. Leadership in Administration: A Sociological Interpretation. Evanston, IL: Row, Peterson.

Silverstein, Mark. 1994. Judicious Choices: The Politics of Supreme Court Confirmations. New York: W. W. Norton.

Sinclair, Barbara. 1988. The Distribution of Committee Positions in the U.S. Senate: Explaining Institutional Change. American Journal of Political Science 32 (2): 276-301.

Squire, Peverill. 1992. The Theory of Legislative Institutionalization and the California Assembly. Journal of Politics 54 (4): 1026-54. 
Stras, David R. 2009. Pierce Butler: A Supreme Technician. Vanderbilt Law Review 62 (2): 695 756.

Swift, Elaine K. 1996. The Making of an American Senate: Reconstitutive Change in Congress, 17871841. Ann Arbor, MI: University of Michigan Press.

US Senate. 2012. Nomination Hearings for Supreme Court Justices. http://www.senate.gov/pagelayout/reference/one_item_and_teasers/Supreme_Court_Nomination_Hearings.htm (accessed September 6, 2012).

Vining, Richard L., Jr. 2011. Grassroots Mobilization in the Digital Age: Interest Group Response to Supreme Court Nominees. Political Research Quarterly 64 (4): 790-802.

Vining, Richard L., Jr., Christopher Zorn, and Susan Navarro Smelcer. 2006. Judicial Tenure on the U.S. Supreme Court, 1790-1868: Frustration, Resignation, and Expiration on the Bench. Studies in American Political Development 20 (2): 198-210.

Washington Post. 2010a. Transcript: The Elena Kagan Hearings-Day 2. http://www.washingtonpost. com/wp-srv/politics/documents/KAGANHEARINGSDAY2.pdf (accessed January 30, 2012). . 2010b. Transcript: The Elena Kagan Hearings-Day 3. http://www.washingtonpost.com/wpsrv/politics/documents/KAGANHEARINGSDAY3.pdf (accessed January 30, 2012).

Watson, George, and John Stookey. 1988. Supreme Court Confirmation Hearings: A View from the Senate. Judicature 71 (4): 186-96.

Wedeking, Justin, and Dion Farganis. 2010. The Candor Factor: Does Nominee Evasiveness Affect Judiciary Support for Supreme Court Nominees? Hofstra Law Review 39 (2): 329-68.

Williams, Margaret, and Lawrence Baum. 2006. Questioning Judges About Their Decisions: Supreme Court Nominees Before the Senate Judiciary Committee. Judicature 90 (2): 73-80.

Yalof, David A. 2008. Confirmation Obfuscation: Supreme Court Confirmation Politics in a Conservative Era. Studies in Law, Politics, and Society 44:143-73.

\section{CASES CITED}

Brown v. Board of Education, 347 U.S. 483 (1954).

Escobedo v. Illinois, 378 U.S. 478 (1964).

Miranda v. Arizona, 384 U.S. 436 (1966).

\section{APPENDIX}

Throughout the article, we identified several specific events that we posit triggered the hearing developments corresponding to Figures $1-4$. To ensure that these events had a statistically significant influence on the dependent variables appearing in these figures, below we report the results of statistical models that allow us to capture the events of interest, while controlling for other factors. Importantly, each of these models corroborates the explanations for the changes to the hearings provided in the article.

Appendix Table 1 is a Poisson model of the number of comments made at the confirmation hearings. We employ a Poisson model in Appendix Tables 1, 2, 3, and 4, since each of the dependent variables is a count that does not exhibit overdispersion. Six independent variables are included in this model. Year of Hearing captures the year the hearing was held. Post-O'Connor is a dichotomous variable, scored 0 for hearings held from 1939-1981 and 1 for hearings held from 1986-2010. Bork is a binary variable, scored 0 for hearings held from 1939-1986 and 1 for hearings held from 1987-2010. This allows us to evaluate whether the increase in hearing dialogue occurred immediately after the O'Connor hearing, as discussed in footnote fifteen. We also include an Ideological Extremism variable that is intended to serve as a proxy for the contentiousness of the nominee. Our expectation is that ideologically extreme nominees will receive more scrutiny from the Committee, evidenced by longer hearings. To operationalize Ideological Extremism, we rely on the Segal and Cover (1989) scores, which provide ideological estimates for Supreme Court nominees 


\begin{tabular}{lc} 
APPENDIX TABLE 1. & \\
Poisson Model of the Number of Comments Made at Supreme Court & \\
Confirmation Hearings, 1939-2010 & \\
\hline Variable & Coefficient \\
\hline Year of Hearing & $0.004^{* * *}$ \\
Post-O'Connor & $(0.001)$ \\
& $0.666^{* * *}$ \\
Bork & $(0.028)$ \\
& $0.431^{* * *}$ \\
Ideological Extremism & $(0.027)$ \\
Divided Government & $1.460^{* * *}$ \\
& $(0.051)$ \\
Committee Size & $0.343^{* * *}$ \\
Constant & $(0.014)$ \\
Pseudo- $R^{2}$ & $0.060^{* * *}$ \\
$N$ & $(0.003)$ \\
\hline
\end{tabular}

Numbers in parentheses are standard errors.

$* * * p<0.05$ (one-tailed tests).

based on newspaper editorials printed between their nomination and Senate confirmation. ${ }^{23}$ These scores range from 0 to 1 , with higher values indicating more liberal ideologies. To measure the ideological extremism of each nominee, we took the absolute value of the nominee's Segal and Cover score after subtracting 0.5 from each score. Consequently, higher scores indicate more ideologically extreme nominees. To assess whether divided government leads to longer hearings, we include a Divided Government variable, scored 1 if the party in control of the Senate differs from that of the president who appointed the nominee and 0 otherwise. Finally, we include a Committee Size variable, which represents the number of senators who questioned the nominee at the confirmation hearings. We expect that the number of comments made at the hearings will increase in response to the number of questioning senators.

Appendix Table 1 corroborates our assertion that the increase in hearing dialogue immediately followed the O'Connor hearing. Specifically, it illustrates that the increase in hearing discussion is attributable primarily to Rehnquist's Chief Justice hearing in 1986 (the first post-O'Connor hearing) as the coefficient associated with the Post-O'Connor variable is more than 50 percent larger than the coefficient associated with the Bork variable. A statistical test of the equality of coefficients indicates that this difference is statistically significant $\left(\chi^{2}=24.8, p<0.001\right)$. This figure also reveals that the number of comments made at the hearings increases for ideologically extreme nominees and during conditions of divided government. Moreover, the number of senators questioning nominees is positively related to the amount of hearing dialogue.

Appendix Table 2 is the alternative specification of the Poisson model of the number of comments made at the confirmation hearings discussed in footnote eighteen. In it, we include all of the variables appearing in Appendix Table 1, with two exceptions. First, in place of the Year of Hearing variable, we include a Polarization variable that captures the difference between the Democratic and

23. We obtained the scores from Jeffrey A. Segal's Web page: http://www.stonybrook.edu/commcms/ polisci/jsegal/QualTable.pdf (accessed May 10, 2013). Note that because Homer Thornberry was not assigned a Segal and Cover score, the $N$ in Appendix Tables 1-4 is 31. 


\section{APPENDIX TABLE 2. \\ Poisson Model of the Number of Comments Made at Supreme Court Confirmation Hearings, 1939-2010}

\begin{tabular}{ll}
\hline Variable & Coefficient \\
\hline Polarization & $0.858^{* * * *}$ \\
Post-O'Connor & $(.104)$ \\
& $0.992^{* * *}$ \\
Ideological Extremism & $(0.019)$ \\
& $1.040^{* * *}$ \\
Divided Government & $(0.044)$ \\
Committee Size & $0.453^{* * *}$ \\
Constant & $(0.014)$ \\
& $0.066^{* * *}$ \\
Pseudo- $R^{2}$ & $(0.003)$ \\
$N$ & $4.376^{* * *}$ \\
& $(0.049)$ \\
\hline
\end{tabular}

Numbers in parentheses are standard errors. $* * * p<0.05$ (one-tailed tests).

Republican Party Senate means based on first dimension DW-NOMINATE scores (Poole 2013). Second, we remove the Bork variable from the model. Note that we do not simultaneously include the Polarization variable and the Year of Hearing and Bork variables owing to multicollinearity: Polarization and Year of Hearing are correlated at 0.97 and Polarization and Bork are correlated at 0.75. Including all three variables in the model simultaneously results in an average variance inflation factor of 13.12. This table reveals that even after controlling for the level of polarization in the Senate, the Post-O'Connor variable continues to exert a strong influence on the number of comments made at the confirmation hearings, further corroborating the conclusions drawn in the article.

Appendix Table 3 is a Poisson model of the number of comments made at the confirmation hearings involving judicial decisions. This model includes the Year of Hearing, Ideological Extremism, Divided Government, and Committee Size variables, as well as a Marshall variable, scored 0 for hearings held before 1967 and 1 for those held from 1967-2010. In addition, we include a Judge variable, scored 1 for nominees who held positions as judges before their nomination and 0 for nominees without such experience. Because judges have a case record from which senators can draw their questions (Williams and Baum 2006), we believe they will receive more questions regarding judicial decisions.

Appendix Table 3 reveals that all of these variables shape the number of comments made at the confirmation hearings devoted specifically to the discussion of judicial decisions. Most importantly, it corroborates our assertion that the Marshall hearing ushered in a new era of hearing discourse. In addition, the discussion of judicial decisions increases for nominees who previously held judgeships, those who are ideologically extreme, and during periods of divided government. However, attention to judicial decisions decreases as the size of the number of questioning senators grows.

Appendix Table 4 is a Poisson model of the number of unique issue areas addressed at the hearings. Again we include the Year of Hearing, Ideological Extremism, Divided Government, and Committee Size variables. In addition, we include a Stevens variable, scored 0 for hearings held before 1975 and 1 for those held from 1975-2010. This table reveals that the only variable that contributed to the increase in the number of issues discussed at the hearings is the Stevens 
APPENDIX TABLE 3.

Poisson Model of the Number of Comments Made at Supreme Court

Confirmation Hearings Devoted to Judicial Decisions, 1939-2010

\begin{tabular}{ll}
\hline Variable & Coefficient \\
\hline Year of Hearing & $0.050^{* * *}$ \\
& $(0.001)$ \\
Marshall & $1.958^{* * *}$ \\
& $(0.102)$ \\
Judge & $0.816^{* * *}$ \\
& $(0.048)$ \\
Ideological Extremism & $1.106^{* * *}$ \\
& $(0.101)$ \\
Divided Government & $0.215^{* * *}$ \\
Committee Size & $(0.030)$ \\
Constant & $-0.094^{* * *}$ \\
Pseudo- $R^{2}$ & $(0.007)$ \\
$N$ & $-93.282^{* * *}$ \\
\hline
\end{tabular}

Numbers in parentheses are standard errors.

$* * * p<0.05$ (one-tailed tests).

variable, thus corroborating our claim that the mid-1970s marked an increase in the breath of issues discussed at the hearings.

Appendix Table 5 is a Tobit model of the percentage of statements made by members of the majority party. We use a Tobit model since the dependent variable is censored between 0

\section{APPENDIX TABLE 4. \\ Poisson Model of the Number of Unique Issues Addressed at Supreme Court Confirmation Hearings, 1939-2010}

\begin{tabular}{ll}
\hline Variable & Coefficient \\
\hline Year of Hearing & 0.009 \\
Stevens & $(0.007)$ \\
& $0.511^{* * *}$ \\
Ideological Extremism & $(0.208)$ \\
Divided Government & -0.469 \\
Committee Size & $0.384)$ \\
Constant & 0.084 \\
Pseudo- $R^{2}$ & $(0.123)$ \\
$N$ & 0.025 \\
& $(0.027)$ \\
& -15.538 \\
$N$ & $(13.745)$ \\
\end{tabular}

Numbers in parentheses are standard errors.

$* * * p<0.05$ (one-tailed tests). 


\section{APPENDIX TABLE 5.}

Tobit Model of the Percentage of Comments Made by Majority Party Senators at Supreme Court Confirmation Hearings, 1939-2010

\begin{tabular}{lc}
\hline Variable & Coefficient \\
\hline Year of Hearing & -0.109 \\
& $(0.249)$ \\
Post-1970s & $-14.724 * * *$ \\
Divided Government & $(8.383)$ \\
& 6.607 \\
Committee Size & $(4.476)$ \\
Constant & -0.390 \\
McKelvey and Zavoina $R^{2}$ & $(0.856)$ \\
$N$ & 291.010 \\
& $(484.295)$ \\
\end{tabular}

Numbers in parentheses are standard errors.

$* * * p<0.05$ (one-tailed tests).

and 100. This model includes the Year of Hearing, Divided Government, and Committee Size variables, in addition to a Post-1970s variable, scored 0 for hearings held before 1981 and 1 for those held from 1981-2010. This table reveals that the Post-1970s variable is the only variable in the model that contributes to the equalization of questioning between members of both political parties on the Committee. This supports our claim that reforms relating to committee assignments and the weakening of the Democratic Party's majority in this era contributed to the equalization of hearing questioning. 